Pierwsza wersja złożona 22.11.2016

Ostatnia wersja zaakceptowana 29.03.2017
ISSN (print) 1689-8966

ISSN (online) 2450-7040

\author{
Aleksandra Luterek*
}

\title{
PROCES PODEJMOWANIA DECYZJI \\ W GOSPODARSTWIE DOMOWYM \\ A DECYDOWANIE W PRZEDSIĘBIORSTWIE - PODOBIEŃSTWA I RÓŻNICE
}

\begin{abstract}
Z a r y s t r e ś c i: Podejmowanie decyzji jest nieodłącznym elementem życia każdego człowieka oraz każdej organizacji funkcjonującej na rynku. Codziennie dokonywane są różne wybory, nie zawsze też w sposób świadomy. Literatura wskazuje jak powinien wyglądać proces, który ostatecznie ma nam pomóc w podjęciu decyzji racjonalnej. Jak się jednak okazuje, w zależności od tego kto daną decyzję podejmuje, skutki są zupełnie inne. Niniejsze opracowanie ma na celu porównanie zachowań i sposobów decydowania przez członków gospodarstwa domowego oraz menedżerów przedsiębiorstwa.
\end{abstract}

S ł o w a k 1 u c z o w e: podejmowanie decyzji, proces decyzyjny, gospodarstwa domowe, przedsiębiorstwa

K 1 a s y f i k a c j JEL: D1, D7

\section{WSTĘP}

Proces podejmowania decyzji towarzyszy codziennie każdej osobie, każdej instytucji. Nawet jeśli nie zawsze ktoś zdaje sobie z tego sprawę, na bieżąco dokonuje wyborów pomiędzy różnymi wariantami. Zgodnie z modelem decyzyjnym, ostateczne rozwiązanie powinno być skutkiem szerszej analizy. W pierwszym etapie powinny zostać uzgodnione wszystkie posiadane warianty wyboru oraz konsekwencje podjęcia każdego z działań,

\footnotetext{
${ }^{*}$ Adres do korespondencji: Aleksandra Luterek, Uniwersytet Warszawski, Wydział Zarządzania, Katedra Systemów Finansowych Gospodarki, Zakład Ubezpieczeń i Rynków Kapitałowych, ul. Szturmowa 1/3, 02-678 Warszawa, e-mail: aluterek@wz.uw.edu.pl
} 
zarówno dla poszczególnych osób, jak i całej organizacji. Następnie określone powinny być preferencje, wskazujące na akceptowalne oraz nieakceptowane skutki pozwalające na odrzucenie wariantów nieodpowiadających całkowitym potrzebom. Ostatecznym kryterium decyzyjnym, na podstawie którego podjęta powinna być końcowa decyzja, jest rezultat najbardziej i najskuteczniej zaspokajający założone potrzeby oraz cele całej organizacji [Bogdanienko, 2010, s. 57].

Niniejsze opracowanie stanowi ocenę procesu podejmowania decyzji przez członków gospodarstw domowych oraz menedżerów przedsiębiorstw. Głównym celem pracy jest porównanie ich zachowań i sposobów decydowania. Opracowanie ma pomóc odpowiedzieć na pytanie czy decydowanie w tych dwóch organizacjach różni się, a jeśli tak to w jakim stopniu i dlaczego.

\section{CZYNNIKI PODEJMOWANIA DECYZJI W GOSPODARSTWACH DOMOWYCH}

Gospodarstwa domowe składają się często nie tylko z jednej osoby (jednoosobowe gospodarstwo domowe). Bardzo powszechne jest tworzenie gospodarstw wieloosobowych, w przypadku których dużo trudniej jest o podjęcie wspólnie akceptowalnej decyzji końcowej. Etapy, które powinny towarzyszyć podejmowaniu tak zwanych racjonalnych decyzji przedstawione zostały na Schemacie 1.

Schemat 1. Model decyzyjny

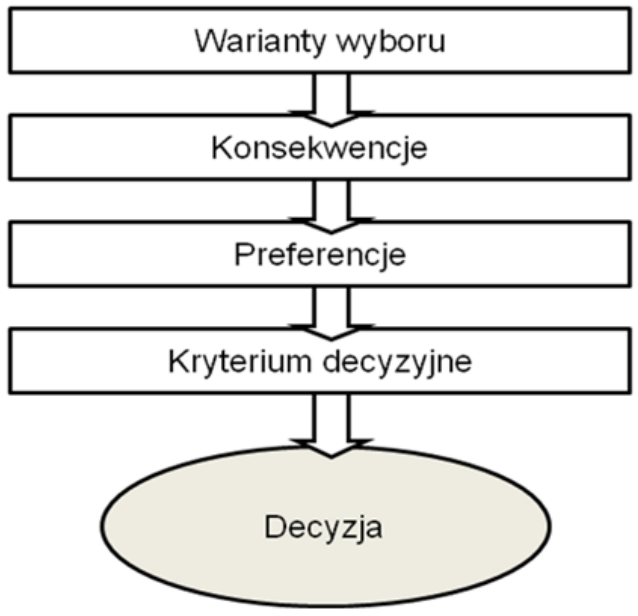

Źródło: Bogdanienko Jerzy, 2010, Organizacja i zarządzanie w zarysie, Wydawnictwo Naukowe Wydziału Zarządzania Uniwersytetu Warszawskiego, Warszawa, s. 57 
Należy pamiętać, że proces podejmowania racjonalnych decyzji powinien opierać się na kompromisach, mających na celu podjęcie decyzji, która będzie satysfakcjonująca dla wszystkich członków rodziny. Niestety, nie jest to proces prosty $\mathrm{z}$ oczywistego względu. Zazwyczaj każda $\mathrm{z}$ osób różni się od siebie w znacznym stopniu. Mogą posiadać różne priorytety, interesować się odmiennymi rzeczami lub zjawiskami. Trudną sztuką wspólnego życia jest umiejętność podjęcia decyzji, która będzie satysfakcjonowała każdego $\mathrm{z}$ osobna, ale także całą grupę. Zdarza się jednak także, że jedna $\mathrm{z}$ osób nie będzie zadowolona $\mathrm{z}$ wyboru, lecz będzie musiała podporządkować się decyzji większości. Podejmowanie grupowych decyzji towarzyszy gospodarstwom domowym każdego dnia, zaczynając od zakupów w supermarkecie, celu podróży wakacyjnej po wybór mieszkania, samochodu czy nawet miejsca pracy poszczególnych członków rodziny. [Timmermans i Zhang, 2009, s. 187-188]

Istotne jest także, że nie ma jednego, prawidłowego i obiektywnie najlepszego sposobu na podjęcie tak zwanej potocznie „dobrej decyzji”. Tak jak i każda osoba różni się od innych osób, tak samo całe gospodarstwa domowe mają odmienne potrzeby, priorytety, preferencje poszczególnych członków oraz interakcje pomiędzy sobą. W związku z tym rodzaj procesu podejmowania decyzji zależy w dużej mierze od rodzaju gospodarstwa domowego. Każde gospodarstwo powinno jednak ostateczną decyzję podjąć tak, by maksymalizować zadowolenie całej rodziny. [Zhang, Kuwano, Lee i Fujiwara, 2009, s. 233] Co więcej, podjęcie konkretnej decyzji przez gospodarstwo domowe zależy od kontekstu, od miejsca, czasu, sytuacji, w której znaleźli się jego członkowie. Podjęcie decyzji w różnych warunkach często skutkuje w pełni odmiennymi końcowymi efektami. [Schwanen i Ettema, 2009, s. 523]

Gospodarstwa domowe różnią się comiesięcznym dochodem, który dość silnie determinuje podejmowane decyzje. Mniej zamożne rodziny nie są w stanie pozwolić sobie na zakup produktów i usług z najwyższych przedziałów cenowych, a jedynie z określonej grupy, dostępnej dla nich ze względu na cenę. Duża część gospodarstw podejmuje decyzje zakupowe szukając produktów zamiennych, substytutów, mających cechy i właściwości jak najbliższe produktowi oryginalnemu, lecz dużo niższą cenę. [Jørgensen i Zaccour, 1999, s. 339] Nie każde gospodarstwo domowe posiada na tyle wysokie zarobki, aby nie patrzeć na koszty funkcjonowania jego członków. Niektóre rodziny, te o bardzo niskich dochodach, nie są zainteresowane na przykład akcjami społecznymi na rzecz certyfikatów ekologicznych dla żywności, ponieważ nie stać ich na droższe produkty nimi oznaczone. W sytuacjach ekstremalnych gospodarstwa domowe muszą podejmować także decyzje, które mogą być trudne i niekomfortowe, na przykład dotyczące przyjmowania pomocy ze strony państwa, wsparcia finansowego pozwalającego na pokrycie opłat obowiązkowych czy bonów pieniężnych na zakupy. [Kaiser i Pulsipher, 2004, s. 774] Zanim jednak 
pozostanie gospodarstwu domowemu do podjęcia taka decyzja, wcześniej jest jeszcze możliwość, z której korzysta większość rodzin, ewentualnej sprzedaży części posiadanego majątku lub zapożyczenia się. Jednak podjęcie decyzji o zapożyczeniu się także wymaga dobrego przygotowania ze strony gospodarstwa domowego ze względu na ryzyko utraty przez rodzinę płynności finansowej. [Cunha, Lambrecht i Pawlina, 2011, s. 1016-1019]

$\mathrm{Na}$ decyzje podejmowane przez gospodarstwa domowe mogą wpływać także różne programy rządowe czy akcje społeczne dotyczące wielu aspektów codziennego życia, takie jak na przykład umiejętność oszczędzania wody czy ograniczania emisji zanieczyszczeń. Jest to aspekt ważny zarówno dla całej gospodarki jak i każdego pojedynczego gospodarstwa domowego, ponieważ dzięki takim akcjom każde $\mathrm{z}$ gospodarstw wdrażające jakieś dodatkowe, nowe działanie, może odnieść pozytywne dla siebie skutki, które mogą odczuć jego członkowie. [Schwarz i Ernst, 2009, s. 505-506] Należy jednak pamiętać, że niezwykle trudno przewidzieć, jak zachowają się członkowie i decydenci danego gospodarstwa domowego, ponieważ nie każdy ma świadomość, jakie działania mogą pozytywnie wpłynąć na kondycję finansową rodziny. Organizacje szacujące ewentualne zyski z wdrażania różnych programów nie mogą posługiwać się jedynie potencjalnymi oszczędnościami gospodarstw domowych. Często, poza czynnikami finansowymi w procesie podejmowania decyzji, gospodarstwa domowe kierują się także innymi, niefinansowymi preferencjami, które niejednokrotnie mogą mieć dla członków gospodarstwa większe znaczenie niż pieniądze. [Jaccard, Loulou, Kanudia, Nyboer, Bailie i Labriet, 2003, s. 148-149]

Na ogółjednak bardzoduża część decyzji podejmowanych przez gospodarstwa domowe dotyczy wydatków konsumpcyjnych. W tym aspekcie znaczący wpływ na podejmowanie decyzji mogą mieć firmy produkcyjne oraz usługowe. Marka jest często bardzo znaczącym czynnikiem wpływającym na zakup określonego produktu. [Nordmoe i Jain, 2000, s. 127-129] Marketingowcy w firmach przeprowadzają wiele analiz, które mają na celu odnalezienie określonej grupy docelowej, gospodarstw domowych, które będą chętne zakupić określony, proponowany im produkt. [Kim, Street, Russell i Menczer, 2005, s. 264] Nie tylko marka przesądza jednak o zakupie, ponieważ nie dla każdego jest ona jedynym wyznacznikiem wartości. Często, na decyzję wpływają głównie czynniki społeczno-demograficzne, ponieważ to one w dużej mierze determinują potrzeby gospodarstw domowych. Jedno z przeprowadzonych badań dotyczyło wpływu tych czynników na wybór środków czystości. Tak, jak wspomniano wcześniej, wiele zależało od rodzaju oraz preferencji członków gospodarstw domowych. Przykładowo było to posiadanie dzieci, chęć i przyjemność z wypróbowywania nowych środków czystości, preferencje dotyczące wyższości jakości nad ceną i odwrotnie, wskazane zostały także podstawowe demograficzne determinanty 
wyboru, takie jak wiek, wykształcenie, wielkość gospodarstwa domowego, zawód, dochód, wielkość miejsca zamieszkania [Hruschka i Natter, 1999, s. 350] Podobne determinanty kształtują rodzaj wybieranego. przez gospodarstwo domowe środka transportu. Wśród nich znalazły się wiek, wielkość gospodarstwa domowego, płeć, zawód, a dodatkowo rodzaj możliwego typu własności pojazdu. [Sasic i Habib, 2013, s. 21] Jak widać gospodarstwa domowe podejmują złożone decyzje zakupowe, nie zawsze biorąc pod uwagę oczekiwaną kwotę wydatku.

\section{PROCES PODEJMOWANIA DECYZJI PRZEZ PRZEDSIĘBIORSTWA}

W przedsiębiorstwach proces podejmowania decyzjijest wspierany rozmaitym oprogramowaniem komputerowym, który ma za zadanie policzyć określone zyski i straty, będące potencjalnym efektem różnych działań. Oprogramowanie komputerowe wspiera podejmowanie decyzji właściwie w każdym aspekcie życia organizacji, począwszy od relacji z klientem, działań marketingowych, profilowania klientów, po wykrywanie oszustw, przewidywania upadłości, diagnostykę medyczną czy odkrycia naukowe. [Shaw, Subramaniam, Tan i Welge, 2001, s. 135] Jest to bardzo duże ułatwienie dla osób decyzyjnych w firmie. Dzięki takim systemom łatwiej jest przewidzieć skutki i podjąć najlepszą strategiczną decyzję, niezależnie od rynku, na jakim funkcjonuje przedsiębiorstwo. [Wong i Monaco, 1995, s. 148; Pullman, Verma i Goodale, 2001, s. 243] Programy takie pomagają analizować cykl życia produktu, umożliwiają przewidzenie, kiedy i ile produkować, aby mieć zapewniony zbyt. Dodatkowo wspierają zarządzanie materiałami czy łańcuchami dostaw, w szybkim czasie umożliwiają analizę wytwarzania różnych kombinacji produktów, które mogą być najefektywniejsze i przynoszące największy możliwy zysk. [Subramoniam, Huisingh i Chinnam, 2009, s. 1164; Closs, Jacobs, Swink i Webb, 2008, s. 590]

Nowe programy wspierające decyzje $\mathrm{w}$ przedsiębiorstwach potrafią rozwiązywać coraz więcej skomplikowanych problemów. Przygotowywane są w taki sposób, aby ograniczać potrzebę angażowania w proces ludzi. Nie oznacza to jednak, że menadżerzy nie są już potrzebni, ale prawdą jest, że niezwykle istotne jest zarządzanie posiadanymi informacjami [Gray, 2001, s. 98], a większość pracy wykonywana jest przez programy komputerowe, łączące wprowadzoną „wiedzę” oraz wydajność, pomagające w krótszym czasie wskazać najlepszą ścieżkę dalszej pracy. [Courtney, 2001, s. 19] Nie powinno się jednak lekceważyć pozycji dobrego menadżera. To dzięki jego umiejętnościom, doświadczeniu i wykształceniu podejmowane decyzje, wsparte technologią, będą najlepiej dopasowane do otoczenia przedsiębiorstwa. [EdumFotwe i McCaffer, 2000, s. 114, 118] Aby system dobrze funkcjonował, należy 
jednak pamiętać o kosztach związanych z wdrażaniem nowych technologii, wspierających podejmowanie decyzji. Szkolenia w zakresie umiejętności korzystania $\mathrm{z}$ oprogramowania są podstawą do pracy oraz możliwości wyciągania prawidłowych wniosków. [Chau i Hu, 2002, s. 298] Należy jednak mieć na uwadze, że oprogramowanie komputerowe wspierające decyzje nie likwiduje $\mathrm{w}$ pełni narażenia przedsiębiorstwa na ryzyko, ponieważ ryzyka nigdy nie da się całkowicie wyeliminować. Wspiera jednak ograniczanie go i pomaga menadżerom szybko podjąć najlepszą decyzję. Nie oznacza to jednak, że możliwość podjęcia błędnej decyzji jest w pełni wykluczona. [Jaafari, 2001, s. 93, 98; Blavatskyy, 2007, s. 260-261]

Komputerowa pomoc w podjęciu decyzji wydaje się także mieć istotne znaczenie dla tych decydentów, charakteryzujących się wysoką awersją do ryzyka, którzy, mając potwierdzenie w liczbach, są w stanie podejmować dużo bardziej innowacyjne i odważne decyzje. [Pennings i Smidts, 2000, s. 1341-1345] Istotne jest, że oprogramowanie lepiej pracuje i lepiej generuje możliwe przyszłe efekty pracy, gdy wprowadzone do niego zostanie więcej szczegółowych danych. W programach jest możliwość wprowadzenia także zadań priorytetowych, które traktowane są jako najważniejsze do zrealizowania. Przykładowo, przepływ informacji w firmie będzie lepszy i łatwiej będzie podjąć strategiczną decyzję dotyczącą kontroli na podstawie wprowadzonych informacji o liczbie roszczeń klientów. Dzięki temu będzie możliwość systematycznego zmniejszania kosztów oraz ograniczenia procedur zakupu towaru. Oprogramowanie komputerowe pomaga w analizie stosowanych rozwiązań. [Van der Aalst, 2001, s. 451; Byun, 2001, s. 295]

Przedsiębiorstwa, tak jak i gospodarstwa domowe, mogą otrzymywać wsparcie finansowe oraz technologiczne od państwa lub różnych organizacji. W przypadku firm ta pomoc nie jest jednak zdeterminowana słabą kondycją finansową, ale perspektywami inwestycyjnymi, rozwojowymi. W tym przypadku, podjęcie decyzji o chęci otrzymywania wsparcia wiąże się z dodatkowym ryzykiem związanym $\mathrm{z}$ wdrażaniem nowych rozwiązań, lecz najważniejsze są obserwowane korzyści w postaci dostępności nowych usług czy redukcji kosztów. [Tung i Rieck, 2005, s. 434]

\section{PODSUMOWANIE}

Na podstawie wybranych badań można zauważyć, że proces podejmowania decyzji towarzyszy codziennie każdej organizacji, zarówno gospodarstwom domowym, jak i przedsiębiorstwom, w każdym okresie ich życia. Zauważalne są jednak pomiędzy nimi różnice $\mathrm{w}$ decydowaniu. Główną z nich jest sam sposób podejmowania decyzji. Członkowie gospodarstw domowych starają się dojść do 
kompromisów, rozmawiają ze sobą, usiłują znaleźć rozwiązanie najlepsze dla każdego z osobna oraz dla całej rodziny a dla decydentów te potrzeby są jednymi z kluczowych czynników warunkujących decyzje. W przedsiębiorstwach zazwyczaj decyzje podejmuje jedna osoba odpowiedzialna, najczęściej menedżer, po ewentualnych ustaleniach z przełożonymi, który „konsultuje” właściwość decyzji z oprogramowaniem komputerowym, na którym opiera się $\mathrm{w}$ obecnych czasach proces podejmowania decyzji w firmach. W tej sytuacji nie mają już kluczowego znaczenia potrzeby każdego z członków organizacji, kwestią kluczową jest zysk i kondycja firmy. To właśnie technologia w głównej mierze determinuje kształt ostatecznych decyzji, a nie subiektywne podejście do problemu jakiejś osoby. Decyzje podejmowane przez gospodarstwa domowe obarczone są jednak większym ryzykiem, ze względu na emocjonalne podejście jego członków i decydentów do różnych spraw w odmiennych sytuacjach. W przedsiębiorstwach wydaje się, że oprogramowanie w dużej mierze ogranicza istniejące ryzyko ze względu na to, że obiektywizuje zadane przez człowieka informacje i pozwala na podejmowanie decyzji nieobarczonych emocjami.

Analizując dostępną literaturę także można stwierdzić, że dostępnych jest bardzo dużo artykułów i badań poświęconych procesowi podejmowania decyzji. Większość z nich porusza jednak problem decydowania w przedsiębiorstwach nie oceniając decyzyjności w gospodarstwach domowych. Jest to obszar, który mógłby zostać rozszerzony o analizy czynników determinujących podejmowanie decyzji w rodzinach.

\section{BIBLIOGRAFIA}

Blavatskyy P. R., (2007), Stochastic expected utility theory, "Journal of Risk and Uncertainty", 34(3), 259-286.

Bogdanienko J., (2010), Organizacja i zarządzanie w zarysie, Wydawnictwo Naukowe Wydziału Zarządzania Uniwersytetu Warszawskiego, Warszawa.

Byun D., (2001), The AHP approach for selecting an automobile purchase model, "Information and Management", 38(5), 289-297.

Chau, P. Y. K., \& Hu P. J., (2002), Investigating healthcare professionals' decisions to accept telemedicine technology: An empirical test of competing theories, "Information and Management", 39(4), 297-311.

Closs D. J., Jacobs M. A., Swink M. \& Webb G. S., (2008), Toward a theory of competencies for the management of product complexity: Six case studies, "Journal of Operations Management", 26(5), 590-610.

Courtney J. F., (2001), Decision making and knowledge management in inquiring organizations: Toward a new decision-making paradigm for DSS, "Decision Support Systems", 31(1), 17-38.

Cunha M. R., Lambrecht B. M. \& Pawlina, G., (2011), Household liquidity and incremental financing decisions: Theory and evidence, "Journal of Business Finance and Accounting", 38(7-8), 1016-1052. 
Edum-Fotwe F. T., \& McCaffer R., (2000), Developing project management competency: Perspectives from the construction industry, "International Journal of Project Management", 18(2), 111-124.

Gray P. H., (2001), A problem-solving perspective on knowledge management practices, "Decision Support Systems", 31(1), 87-102.

Hruschka H. \& Natter M., (1999), Comparing performance of feedforward neural nets and K-means for cluster-based market segmentation, "European Journal of Operational Research", 114(2), 346-353.

Jaafari A., (2001), Management of risks, uncertainties and opportunities on projects: Time for a fundamental shift, "International Journal of Project Management", 19(2), 89-101.

Jaccard M., Loulou R., Kanudia A., Nyboer J., Bailie A. \& Labriet M., (2003), Methodological contrasts in costing greenhouse gas abatement policies: Optimization and simulation modeling of micro-economic effects in Canada, "European Journal of Operational Research", 145(1), 148-164.

Jørgensen S. \& Zaccour G., (1999), Price subsidies and guaranteed buys of a new technology, "European Journal of Operational Research", 114(2), 338-345.

Kaiser M. J., \& Pulsipher A. G., (2004), The design of a dynamic allocation mechanism for the federal energy assistance program LIHEAP, "European Journal of Operational Research", 158(3), 773-792.

Kim Y., Street, W. N. Russell, G. J. \& Menczer F., (2005), Customer targeting: A neural network approach guided by genetic algorithms, "Management Science", 51(2), 264-276.

Nordmoe E. D. \& Jain D. C., (2000), Drawing inferences from logit models for panel data, "Applied Stochastic Models in Business and Industry", 16(2), 127-145.

Pennings J. M. E. \& Smidts A., (2000), Assessing the construct validity of risk attitude, "Management Science", 46(10), 1337-1348.

Pullman M. E., Verma R. \& Goodale J. C., (2001), Service design and operations strategy formulation in multicultural markets, "Journal of Operations Management", 19(2), 239254.

Sasic A. \& Habib K. N., (2013), Modelling departure time choices by a heteroskedastic generalized logit (het-GenL) model: An investigation on home-based commuting trips in the greater toronto and hamilton area (GTHA), "Transportation Research Part A: Policy and Practice", 50, 15-32.

Schwanen T. \& Ettema D., (2009), Coping with unreliable transportation when collecting children: Examining parents' behavior with cumulative prospect theory, "Transportation Research Part A: Policy and Practice", 43(5), 511-525.

Schwarz N. \& Ernst A., (2009), Agent-based modeling of the diffusion of environmental innovations - an empirical approach, "Technological Forecasting and Social Change", 76(4), 497-511.

Shaw M. J., Subramaniam C., Tan G. W. \& Welge M. E., (2001), Knowledge management and data mining for marketing, "Decision Support Systems", 31(1), 127-137.

Subramoniam R., Huisingh D. \& Chinnam R. B., (2009), Remanufacturing for the automotive aftermarket-strategic factors: Literature review and future research needs, "Journal of Cleaner Production", 17(13), 1163-1174.

Timmermans H. J. P. \& Zhang J., (2009), Modeling household activity travel behavior: Examples of state of the art modeling approaches and research agenda, "Transportation Research Part B: Methodological", 43(2), 187-190.

Tung L. L. \& Rieck O., (2005), Adoption of electronic government services among business organizations in Singapore, "Journal of Strategic Information Systems", 14(4), 417-440.

Van der Aalst W. M. P., (2001), Re-engineering knock-out processes, "Decision Support Systems", 30(4), 451-468. 
Wong B. K. \& Monaco J. A., (1995), Expert system applications in business: A review and analysis of the literature (1977-1993), "Information and Management", 29(3), 141-152.

Zhang J., Kuwano M., Lee B. \& Fujiwara A., (2009), Modeling household discrete choice behavior incorporating heterogeneous group decision-making mechanisms, "Transportation Research Part B: Methodological”, 43(2), 230-250.

\title{
DECISION-MAKING PROCESS IN HOUSEHOLDS A DECISION IN THE COMPANY - RELATIONSHIP AND DIFFERENCES
}

\begin{abstract}
Decision-making is an integral part of life of every person and every organization functioning in the market. Different choices are made every day, not always in a conscious way. Literature shows us how a process that will ultimately help us make rational decisions should look like. As it turns out, depending on who makes the decision, the effects are quite different. This study aims to compare the behavior and ways of deciding of households and businesses.
\end{abstract}

Keywords: decision-making, decision-making process, households, business 
